\title{
Zika and spontaneous abortion
}

\author{
Zika y aborto espontáneo \\ Beuy Joob ${ }^{1 *}$ y Viroj Wiwanitkit ${ }^{2}$ \\ ${ }^{1}$ Instalaciones Sanitarias, Medical Academic Center, Bangkok, Tailandia; ${ }^{2}$ Dr. DY Patil University, Pune, India
}

Dear Editor,

We read the publication on "Zika as a cause of spontaneous abortion in endemic areas" with a great interest ${ }^{1}$. Rivadeneyra-Espinar et al. ${ }^{1}$ concluded that "Zika infection during pregnancy must be suspected and diagnosed promptly to offer comprehensive care. The loss of conception in these patients has been documented with results of chorionic villus biopsies, finding Zika virus (ZIKV) RNA and suggesting spontaneous abortion early during viremia"1. In the present report, Rivadeneyra-Espinar et al. ${ }^{1}$ reported a case, which is concordant with another recent report by Goncé et al. ${ }^{2}$ We would like to share some ideas with this case report.

First, ZIKV infection is endemic in several areas of the world and most of the cases are asymptomatic ${ }^{3}$. Focusing on the pregnant subject, the infection can occur and might or might not affect the pregnancy outcome and infant health. The persistence of the virus in the placental tissue is possible but does not confirm the relationship between viral infection and abortion or fetal pathology or infantile health problems ${ }^{4}$. In tropical Southeast Asia, Zika is also an endemic disease and there are many infected pregnant subjects. However, to the extent of our knowledge, no studies on the intrapartum ZIKV infection related to abortion in Southeast Asia have been reported 5 . In an area with high rate of
ZIKV immunoreactivity, such as Cambodia $^{6}$, no reports have been published on the congenital ZIKV syndrome or spontaneous abortion in pregnant women. Indeed, there are no previous studies on testing for acute or recent infections with ZIKV among women who have had spontaneous abortions. The exact pathological relationship between the presence of ZIKV in the chorionic villi and pregnancy outcome should be further researched.

\section{Conflicts of interest}

The authors declare that they have no conflicts of interest.

\section{References}

1. Rivadeneyra-Espinar PG, Venegas-Esquivel GA, Díaz-Espinoza CM, Pérez-Robles VM, González-Fernández MI, Sesma-Medrano E. Zika as a cause of spontaneous abortion in endemic areas. Bol Med Hosp Infant Mex. 2019;76:193-7.

2. Goncé A, Martínez MJ, Marbán-Castro E, Saco A, Soler A, Alvarez-Mora MI, et al. Spontaneous abortion associated with zika virus infection and persistent viremia. Emerg Infect Dis. 2018;24:933-5.

3. Wiwanitkit S, Wiwanitkit V. Afebrile, asymptomatic and non-thrombocytopenic zika virus infection: don't miss it! Asian Pac J Trop Med. 2016;9:513.

4. Santos GR, Pinto CA, Prudente RC, Bevilacqua EM, Witkin SS Passos SD, et al. Case report: histopathologic changes in placental tissue associated with vertical transmission of zika virus. Int J Gynecol Pathol. 2019. DOI: 10.1097/PGP.0000000000000586.

5. Wiwanitkit V. The current status of zika virus in Southeast Asia. Epidemiol Health. 2016;38:e2016026.

6. San K, Rajadhan V. Seroprevalence of zika virus in Cambodia: a preliminary report. Adv Lab Med Int. 2016;6:37-40.

\section{Correspondencia:}

*Beuy Joob

E-mail: beuyjoob@ hotmail.com

1665-1146/@ 2019 Hospital Infantil de México Federico Gómez. Publicado por Permanyer. Este es un artículo open access bajo la licencia CC BY-NC-ND
Disponible en internet: 17-02-2020 Bol Med Hosp Infant Mex. 2020;77(1):46 www.bmhim.com 